\title{
Chemical and microbiological comparison of biodeterioration in Colombian heritage constructions
}

\author{
Luis Gonzalo Sequeda-Castañeda ${ }^{1}$, Andrés Eduardo Ortiz-Ardila ${ }^{2}$, Jennifer Paola Correa- \\ Cuadros $^{3}$, Cecilia López-Pérez ${ }^{4}$
}

\begin{abstract}
Mortars from Bogotá, Villa de Leyva and Barichara were compared chemically and microbiologically. We analyzed the samples using atomic absorption and emission spectrometry, Fourier-transform infrared spectroscopy, X-ray diffraction, scanning electron microscopy and energy dispersive spectroscopy. Oxides of silicon, aluminum, calcium, iron, magnesium, gypsum, weddellite, despujolsite, quartz, berlinite, carbonate, mica, feldspars, silicates, nitrate salts, sulfites, and organic compounds were identified. In addition, irregular particles between 10, 50 an $100 \mu \mathrm{m}$ were found, as well organic fibers of $20 \mu \mathrm{m}$. Was performed a CFU count using a dilution method to identify fungal microorganisms and found following genera Aspergillus, Penicillium, Alternaria, Fusarium, Mucor and Syncephalastrum. The mortar sample taken in Bogotá presented the highest number of $\mathrm{CFU} / \mathrm{mL}$ and the highest percentage of relative humidity. The concentration of fungi in this sample, unlike those from Villa de Leyva and Barichara, caused degradation in most of the metals identified. This chemical and microbiological comparison proposes an effective plan of action to eliminate and prevent biodeterioration in support of the conservation of heritage constructions.
\end{abstract}

Keywords: Biodeterioration, mortars, FTIR, XRD, SEM, EDX, fungi, architectural heritage, chemistry, microbiology

1 Departamento de Química, Facultad de Ciencias. Pontificia Universidad Javeriana. Bogotá, D.C., Colombia.

2 Departamento de Microbiología, Facultad de Ciencias. Pontificia Universidad Javeriana. Bogotá, D.C., Colombia.

3 Departamento de Biología, Facultad de Ciencias. Pontificia Universidad Javeriana. Bogotá, D.C., Colombia.

4 Departamento de Arquitectura, Facultad de Arquitectura y Diseño. Pontificia Javeriana. Bogotá, D.C., Colombia.
Comparación química y microbiológica del biodeterioro en construcciones patrimoniales en Colombia. Resumen. Se compararon química y microbiológicamente morteros de Bogotá, Villa de Leyva y Barichara. Las muestras se analizaron por espectrometría de absorción y emisión atómica, espectroscopia infrarroja con transformada de Fourier, difracción de Rayos X, microscopía electrónica de barrido y espectroscopia por dispersión de energía. Se encontraron óxidos de silicio, aluminio, calcio, hierro, magnesio, yeso, weddellita, despuljosita, cuarzo, berlinita, carbonatos, mica, feldespatos, silicatos, sales de nitratos, sulfitos y compuestos orgánicos. A su vez, se hallaron partículas irregulares entre 10, 50 y 100 $\mu \mathrm{m}$ y fibras de tipo orgánico de $20 \mu \mathrm{m}$. Se realizó el conteo de unidades formadoras de colonias por el método de diluciones para identificar microorganismos fúngicos. Se identificaron los siguientes géneros Aspergillus, Penicillium, Alternaria, Fusarium, Mucor y Syncephalastrum. La muestra de Bogotá presentó el mayor número de UFC/mL y el mayor porcentaje de humedad relativa. La concentración de hongos en esta muestra, a diferencia de las de Villa de Leyva y de Barichara, causó la degradación de la mayoría de los metales identificados. Esta comparación química y microbiológica propone un plan eficaz de intervención para eliminar y prevenir el biodeterioro en apoyo a la conservación de obras patrimoniales.

Resumo. As amostras foram analisadas por espectrometria de emissão e espectroscopia de absorção atômica, infravermelho com transformada de Fourier, difração de raios X, microscopia eletrônica de varredura e espectroscopia de energia dispersiva. Foram identificados óxidos de silício, alumínio, cálcio, ferro, magnésio, gesso, weddellita, despuljosita, quartzo, berlinita, carbonato, mica, feldspato, silicatos, sais de nitratos, sulfitos, e compostos orgânicos. Partículas irregulares entre os 10, 50 e 100 $\mu \mathrm{m}$ foram encontradas bem como fibras de tipo orgânico de $20 \mu \mathrm{m}$. Realizou-se uma contagem CFU usando um método de diluição para identificar microorganismos fúngicos e encontrouse fungos dos gêneros Aspergillus, Penicillium, Alternaria, Fusarium, Mucor Syncephalastrum. A amostra de Bogotá apresentou o maior número de $\mathrm{UFC} / \mathrm{mL}$ e umidade relativa do ar. A maior presença de fungos desta amostra, ao contrário das amostras da Villa de Leyva e Barichara, causou degradação na maioria dos metais identificados. Esta comparação química e microbiológica pode sugerir um plano de ação eficaz para a eliminação e prevenção da biodegradação e assim preservar obras patrimoniais. 


\section{Introduction}

A mortar is made up of a mixture of lime, dirt, vegetable juices, rubbers, honey, bees wax and natural fibers (Ventola et al. 2011) coated with lime and natural pigments or ochre (Corradine 1989, López 2009) comprised of an aggregate and a binder, its nature is varied and in some cases specific to each region (Garg et al. 1995). These plasters are used to coat different types of constructions to protect the walls from the effects of weather or other extrinsic factors that may cause deterioration (Nuhoglu et al. 2006). They have been used extensively in Colombian architecture in both indoor and outdoor applications, in masonry exposed to dry air as well as in buildings near salt water (Corradine 1989).

One of the greatest problems facing heritage construction is biodeterioration; this is an adverse change in the properties of the material caused by the microorganisms activity (Garg et al. 1995, Herrera and Videla 2004, Gaylarde et al. 2006 and Nuhoglu et al. 2006). Traditional techniques of monument restoration, to combat the effects of biodeterioration, are ineffective since there is no compatibility between the finish and the support element (dirt). Also, there are no established methods of analysis to determine the composition of the mortars and no interdisciplinary studies to identify the pathologies that affect them (Lee 2009). Thus, research becomes necessary to identify the chemicals and microorganisms that cause biodeterioration to implement restoration and preservation solutions in heritage buildings of architectural interest (Corradine 1989, Lopez 2009).

The study of biology applied to restoration is relatively new and its field of interest is broad and multidisciplinary, where biodeterioration becomes foremost since it encompasses several factors such as microorganisms, substrate characteristics and environmental conditions (Caneva et al. 2000).

In general, the deterioration of buildings of architectural interest is a result of direct exposure to environmental elements such as sun, wind, rain and air pollution (Herrera et al. 2004, Herrera and Videla 2004). However, biodeterioration requires environmental factors such as rainfall, humidity and the availability of a substrate to be assimilated by the microorganisms (Garg et al. 1995, Herrera and
Videla 2004, Nuhoglu et al. 2006). One example is fungal biofilms, which obstruct the material's pores hindering water evaporates. Because water is being collected and not evaporated, it causes the mortar to separate into "crusts" (Heitz et al. 1990, Hirsh et al. 1995, Sand 1997, Sanjurjo-Sánchez et al. 2010).

The nature of mortar and its wealth of organic elements make it a readily colonizable habitat for autotrophic (producers) microorganisms, which then facilitate the arrival and settlement of heterotrophs (consumers and destroyers) such as fungi (Nuhoglu et al. 2006). Producers do not directly use the materials to satisfy their metabolic requirements (except mineral salts), they indirectly degrade the substrate for consumers that use the organic matter for their sustenance, thus deteriorating the mortar (Caneva et al. 2000). The most essential macronutrients for consumers are $\mathrm{K}, \mathrm{Ca}, \mathrm{S}, \mathrm{Mg}$ and $\mathrm{P}$ and $\mathrm{N}$ salts. The most important micronutrients are $\mathrm{Mn}, \mathrm{Fe}$, $\mathrm{Zn}$ and Si (Garg et al. 1995, Herrera and Videla 2004, Rampazzi et al. 2004). The biodeterioration of mortars by these microorganisms, according to the type of damage, can be divided into two classes: chemical and physical damage. The first is when the effect is mediated by enzymes and/or secondary metabolites (Garg et al. 1995, Sand 1997) and the second is caused by the mechanical trauma of penetration, colonization and growth of the microorganisms in the mortar substrate (Garg et al. 1995, Gaylarde et al. 2006, Sterflinger 2010).

Chemical and microbiological analyses may help develop an effective plan of action for the elimination and prevention of biodeterioration. It can be helpful for restorers and curators, as it contributes to the understanding of the biology behind the process and sheds light on the applications of microbiology and chemistry in the conservation of heritage constructions. Therefore, this study compared the chemical and microbiological biodeterioration of mortars in three cities of Colombia, Bogotá, Villa de Leyva and Barichara.

\section{Materials and methods}

Area of study: The buildings sampled are in three major cities of Colombia: Bogotá (Cundinamarca), Villa de Leyva (Boyacá) and Barichara (Santander). 
We selected heritage constructions of different types and uses, located in different climates and altitudes where the samples could be easily extracted from the mortar. The first building selected was La Casa de Hacienda El Otońo (national monument) in Bogotá, which is part of a larger expanse of land called the "Hacienda el Otoño" (Figure 1). Lopez (2009) reveals it dates back to the seventeenth century (1675) when it belonged to the Jesuit Community. The site once extended from: the existing 170th Street, to the south; to the limits of Chia, in the north; the Autopista Norte (northern highway), to the west; and the Bogotá River, to the east (Lopez 2009).
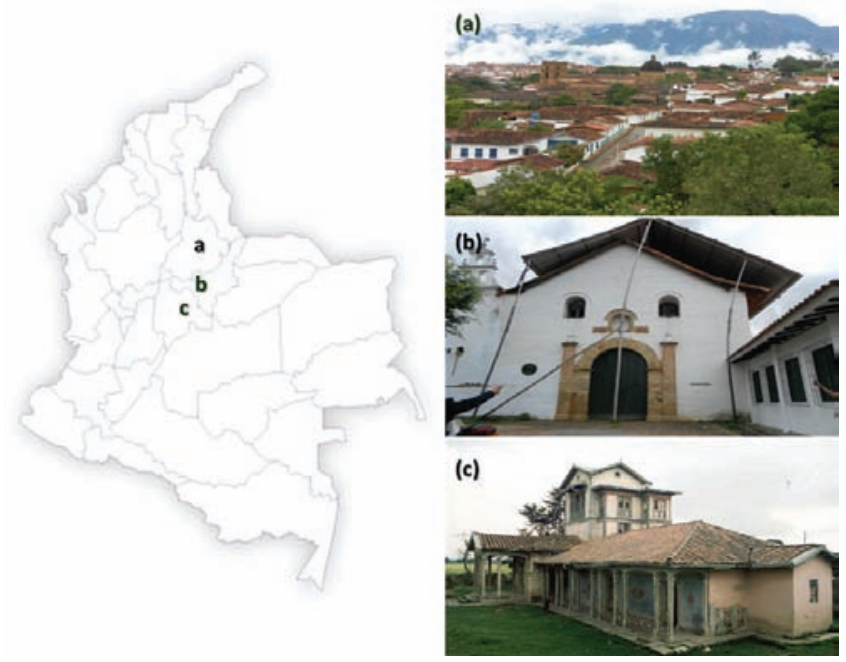

Fig 1. Location and current state of the buildings. (a) Barichara (Santander). (b) Villa de Leyva (Boyacá), Claustro de San Francisco. (c) Bogotá D.C. (Bogotá D.C.), Casa de Hacienda El Otońo.

The second building was the Claustro de San Francisco, located in the town of Villa de Leyva, in the Province of Ricaurte, Department of Boyacá. The cloister, according to Barichara (2011) dates back to 1613, when the founding of the Convent of San Francisco was approved during a town hall meeting. At the present, the church presents a high degree of deterioration (Figure 1). Lastly, the third property is located in Barichara (Santander), in the province of Guanentá. Samples for the study were taken from houses, which now stand on Second Street and Third Avenue where during the mid-twentieth century the "Carretera del noroeste (northwest highway)" was built. The purpose of the building has changed on several occasions but its historical analysis establishes its construction circa 1617 (Barichara 2011).

The sampled properties correspond to eras beginning in the seventeenth century. The buildings are all located at different sea level, in different temperatures and have different rainfall conditions (Table 1).

Table 1. General environmental characteristics of sampling sites. Source Ideam (2012). ${ }^{1}$ masl: meters above sea level

\begin{tabular}{llll}
\hline & \multicolumn{3}{c}{ City } \\
\cline { 2 - 4 } Parameter & Barichara & $\begin{array}{l}\text { Villa de } \\
\text { Leyva }\end{array}$ & Bogotá \\
\hline Climate & Warm dry & $\begin{array}{l}\text { Warm } \\
\text { desert and } \\
\text { paramo }\end{array}$ & $\begin{array}{l}\text { Tropical } \\
\text { cold }\end{array}$ \\
& & 2143 & 2630 \\
$\begin{array}{l}\left.\text { Elevation (masl }{ }^{1}\right) \\
\text { Temperature }\left({ }^{\circ} \mathrm{C}\right)\end{array}$ & 1336 & $7-25$ & $8-20$ \\
$\begin{array}{l}\text { Relative humidity } \\
(\%)\end{array}$ & $25-38$ & $40-74$ & $45-96$ \\
$\begin{array}{l}\text { Rainfall (mm/ } \\
\text { month) }\end{array}$ & $26-147$ & $69-160$ & $31-172$ \\
\hline
\end{tabular}

Samples and sampling points: For the chemical and microbiological analysis, we collected a total of 33 samples $(5 \mathrm{~g}$ each) of mortars from Bogotá (Sample 1), Villa de Leyva (Sample 2) and Barichara (Sample 3). Each property was randomly sampled in areas permitted by the owner, which evidenced some degeneration in the mortar. Only on repetition was performed at each sample point. Eleven samples were obtained in Bogotá, 13 in Villa de Leyva and 9 in Barichara. Sampling was carried out following the methodology of Böke et al. (2008), which entailed scraping the surface and removing a small sample of the mortar using scalpel blades and sterile spatulas. The samples were taken from areas presenting cracking and swelling in the mortar's surface layers.

The samples were kept in sterile plastic vials at room temperature while transported to the Microbiological Chemistry and Materials Laboratory of the Department of Chemistry, Faculty of Science at the Pontificia Universidad Javeriana. To compare between the three types of mortar and 
have representativity of each one of these points as well as to avoid uncontrolled factors such as spatial variability, composite samples were taken for each sampling point.

Chemical analysis: A pooled sample was obtained for each sampling point, then ground using an agate mortar and dried at $100^{\circ} \mathrm{C}$ for 3 hours. Approximately $500 \mathrm{mg}$ were dissolved with hydrochloric acid (1:9), one part of concentrated acid and nine parts of deionized water at a temperature of 60 ${ }^{\circ} \mathrm{C}$ for 3 days using sonication. Subsequently, each composite sample was left in a water bath for a day. Compounds such as $\mathrm{CaO}, \mathrm{MgO}, \mathrm{Al}_{2} \mathrm{O}_{3}$ and $\mathrm{Fe}_{2} \mathrm{O}_{3}$ were analyzed by atomic absorption spectrometry using Varian AA140 equipment. To determine $\mathrm{SiO}_{2}$ solubility, $500 \mathrm{mg}$ of each sample was solubilized with hydrochloric acid at $10 \%$, the filtrate was then analyzed by atomic emission spectroscopy (Varian AA140). The results were used to calculate the hydraulic index "i" and cementation index "CI", according to the following equations: $\mathrm{i}=\left(\% \mathrm{Al}_{2} \mathrm{O}_{3}\right.$ $\left.+\% \mathrm{Fe}_{2} \mathrm{O}_{3}+\% \mathrm{SiO}_{2}\right) /(\% \mathrm{CaO}+1.4 \times \% \mathrm{MgO})$, $\mathrm{CI}=\left(2.8 \times \% \mathrm{SiO}_{2}+1.1 \times \% \mathrm{Al}_{2} \mathrm{O}_{3}+0.7 \times \% \mathrm{Fe}_{2} \mathrm{O}_{3}\right)$ / $(\% \mathrm{CaO}+1.4 \times \% \mathrm{MgO})$ (Callebaut et al. 2001).

The dissolution of the mortar in hydrochloric acid yielded three fractions: the insoluble fraction formed by aggregates, the soluble fraction from calcium content and others, and the volatile fraction. For this, we used the methodology proposed by Quarcioni and Cincotto (2006). At room temperature, we used $500 \mathrm{mg}$ of each sample to establish the insoluble residue using hydrochloric acid in a (1:2) ratio, mechanically shaken and heated in boiling water for 60 minutes. Afterward, the residue was washed with a sodium carbonate solution (10\%).

The concentration of calcium, iron, aluminum and magnesium was determined using atomic absorption spectrometry and atomic emission spectrometry for silicium (FAAS, FAES), using a Varian AA140 spectrometer with an air-acetylene and acetylene/ nitrous oxide burner head. As a standard for calcium, iron, aluminum, magnesium and silicium, stock solutions of 1000 ppm of JT Baker and lanthanum oxide at $500 \mathrm{ppm}$ of Sigma. The calibration curves for the analytes were performed according to the equipment manufacturer workbook (Agilent 2012). The determination of vibration frequencies (characteristic of the compounds present in mortars) in the 4000 to $400 \mathrm{~cm}^{-1}$ range, was accomplished using an Shimadzu IR 8300 Fourier-transform infrared spectrometer (FTIR), where the powder samples were suspended in spectroscopic grade $\mathrm{KBr}$ of Sigma in a ratio of $1 \mathrm{mg}$ of sample in $100 \mathrm{mg}$ of $\mathrm{KBr}$ (Quarcioni and Cincotto 2006, Gleize et al. 2009).

The X-ray diffraction (XRD) technique was used to obtain diffractograms using Panalytical X'Pert PRO MPD system, set to a measuring range between 2 to $70^{\circ}(2 \theta)$, a step size of $0.02^{\circ}(2 \theta)$, and a time per step of 0.4 seconds, $\mathrm{CuK} \alpha 1$ radiation $(\lambda=1.5406 \AA)$, and LynxEye detector. The qualitative identification of crystalline phases present in the composite samples from Bogotá, Villa de Leyva and Barichara was performed by comparing the measured profile reflections with the reflections of diffraction profiles reported in the Powder Diffraction File (PDF-2) database of the International Center for Diffraction Data (ICDD) using Search Match software. Sample preparation was carried out in an agate mortar and ground to a grain size of less than $0.063 \mathrm{~mm}$. The particle morphology was evaluated using scanning electron microscopy (SEM) the equipment used was a JEOL microscope, model JSM 6490-LV, operated in high vacuum mode and equipped with detectors that allow imaging of ET-type secondary electrons (Everhart-Thorneley). Under low pressure $10^{-4}$ torr, sample fragments were coated with a layer of gold to obtain high quality images. The energy dispersive spectroscopy (EDX) detector made possible the qualitative microanalysis (Quarcioni and Cincotto 2006, Gleize et al. 2009).

Statistical analysis: To compare the chemical compounds (silica, alumina, hematite, lime, magnesium, moisture, insoluble residue and loss on ignition) of the three sampling points (Bogotá, Villa de Leyva and Barichara); we completed a random test using a one-way ANOVA, to establish differences between the samples according to each compound. In addition, multiple a-posteriori comparisons were performed between the samples using the Scheffe test to identify the sample with the highest amount of compound, when these differed statistically. The tests were conducted using SPSS 19 software. Most of the compounds met the three 
assumptions of parametric statistics (normality, homogeneous variance and sample independence); except the hematite compound, which did not meet the assumption of homogeneity of variances, even after square root data transformation, therefore, a nonparametric Kruskal-Wallis test was conducted with a subsequent post-hoc test.

Microbiological analysis: Using the dilution method, we performed a CFU/mL (colony forming units per milliliter) count by preparing a $0.1 \mathrm{~mL}$ surface plate spread of inoculum for the last two dilutions $\left(10^{-4}\right.$ and $\left.10^{-5}\right)$ on the following synthetic mediums: Rose bengal, malt extract, and Sabouraud (Merck), then incubated the microorganisms at 25 ${ }^{\circ} \mathrm{C}$ for 8 days. The fungal individuals obtained were isolated and purified by inoculation on different PDA, Czapeck, Sabouraud, Malt extract and oatmeal agar) to observe the reaction of their reproductive structures to different types and concentrations of substrates and thus achieve a better identification. Optical microscopy (Motic B1-211A) and different staining techniques, such as Gram, lactophenol blue and $40 \% \mathrm{KOH}$ were used. Lastly, we observed and identified the specific reproductive structures of each of the fungal type samples, and used the taxonomic key by Samson et al. (2004) to determine family and genus.

\section{Results}

Chemical analysis of mortars: Were tested each of the composite samples to determine the presence of silicon, aluminum, iron, calcium and magnesium, in the results of theses tests, these materials are expressed as oxides. We also determined the moisture content, insoluble residue, loss on ignition. Hydraulic and cementation indeces were calculated in all of the samples (Table 2). The statistical analysis comparing the amount of each one of the compounds tested in each one of the samples (Bogotá, Barichara Leyva Villa) showed that there were no significant differences regarding silicium and insoluble residue. In contrast, alumina, hematite, lime, magnesium, humidity and loss on ignition had significant differences (Table 2).

Atomic absorption/emission spectrometry (AAS/ AES): The content of soluble metals (Table 2) is expressed as oxides in the form of silica $\left(\mathrm{SiO}_{2}\right)$, alumina $\left(\mathrm{Al}_{2} \mathrm{O}_{3}\right)$, hematite $\left(\mathrm{Fe}_{2} \mathrm{O}_{3}\right)$, lime $(\mathrm{CaO})$ and magnesium $(\mathrm{MgO})$. The results indicated that the silica and lime content in the Bogotá sample was lower than in the Villa de Leyva and the Barichara samples, but had higher humidity, insoluble residue and loss on ignition values. The Villa de Leyva sample presented the highest level of alumina, magnesium and hematite, while the Barichara sample had higher values of silica and lime.

Table 2. Mortar samples' physicochemical composition (\%) and statistical analysis. Mean \pm standard deviation $(\mathrm{n}=4$ replicates). NC: Not comparable. ${ }^{a}$ F Fischer of ANOVA, except hematite ( $\mathrm{Chi}^{2}$, nonparametric Kruskal-Wallis test). ${ }^{b}$ Test significance with a 95\% probability. ${ }^{\mathrm{c}}$ A-posteriori Scheffe test.

\begin{tabular}{|c|c|c|c|c|c|c|}
\hline Determination & Bogotá & Villa de Leyva & Barichara & $\mathbf{F}^{\mathbf{a}}$ & $P(<0.05)^{b}$ & Scheffe ${ }^{c}$ \\
\hline Alumina $\mathrm{Al}_{2} \mathrm{O}_{3}$ & $2.54 \pm 0.41$ & $3.01 \pm 0.25$ & $1.23 \pm 0.18$ & 28,196 & 0,001 & Vill $>$ Bta $>$ Bar \\
\hline Humidity & $6.85 \pm 0.55$ & $4.47 \pm 0.78$ & $3.47 \pm 0.24$ & 29,053 & 0,001 & Bta $>$ Vill $>$ Bar \\
\hline Lime $\mathrm{CaO}$ & $17.9 \pm 0.07$ & $19.9 \pm 0.08$ & $22.5 \pm 0.87$ & 9,545 & 0,014 & Bar $>$ Vill $>$ Bta \\
\hline Loss on ignition & $8.47 \pm 1.01$ & $6.78 \pm 0.18$ & $5.56 \pm 0.81$ & 7,67 & 0,022 & Bta $>$ Vill $>$ Bar \\
\hline Magnesium MgO & $1.42 \pm 0.02$ & $1.52 \pm 0.04$ & $0.78 \pm 0.12$ & 5,635 & 0,042 & Vill $>$ Bta $>$ Bar \\
\hline Hematite $\mathrm{Fe}_{2} \mathrm{O}_{3}$ & $1.98 \pm 0.05$ & $2.23 \pm 0.09$ & $1.45 \pm 0.51$ & 5,85 & 0,054 & Vill $>$ Bta $>$ Bar \\
\hline Insoluble residue & $51.0 \pm 1.89$ & $49.2 \pm 1.63$ & $48.1 \pm 1.18$ & 2,504 & 0,157 & \\
\hline Silica $\mathrm{SiO}_{2}$ & $2.56 \pm 0.67$ & $2.78 \pm 0.57$ & $3.68 \pm 0.75$ & 2,367 & 0,175 & \\
\hline Hydraulic index & 0.367 & 0.373 & 0.268 & $\mathrm{NC}$ & $\mathrm{NC}$ & $\mathrm{NC}$ \\
\hline Cementation index & 0.572 & 0.573 & 0.519 & $\mathrm{NC}$ & $\mathrm{NC}$ & $\mathrm{NC}$ \\
\hline
\end{tabular}

${ }^{a}$ Confirmed by MS data ${ }^{b}$ Uncorrected, ${ }^{c}$ Isolated yield after CC. 
Fourier-transform infrared spectroscopy (FTIR): FTIR spectra (Figure 2) of the Bogotá, Villa de Leyva and Barichara samples confirmed the presence of a doublet at 796 and $779 \mathrm{~cm}^{-1}$ and a band at $694 \mathrm{~cm}^{-1}$, characteristic of $\alpha$-quartz $\left(\alpha-\mathrm{SiO}_{2}\right)$ corresponding to symmetric bending of the Si-O bond (Mleza and
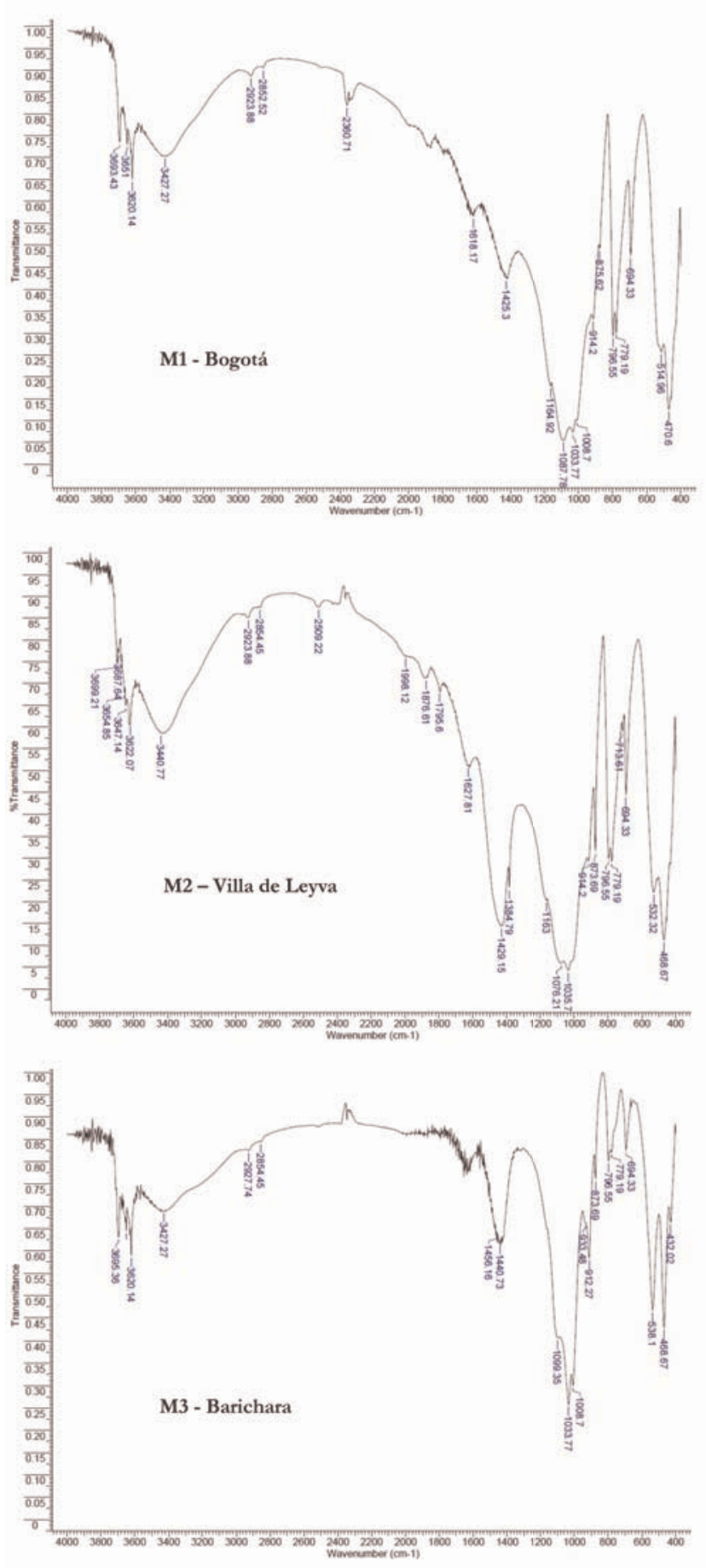

Hajjaji 2012).

In calcite compounds $\left(\mathrm{CaCO}_{3}\right)$ and amorphous silica $\left(\mathrm{SiO}_{2}\right)$ resulting from the calcination of limestone, which produces lime, the following bands are observed: 1425, 875 and $468 \mathrm{~cm}^{-1}$ from Bogotá; at 1429, 873, 713 and $468 \mathrm{~cm}^{-1}$ from Villa
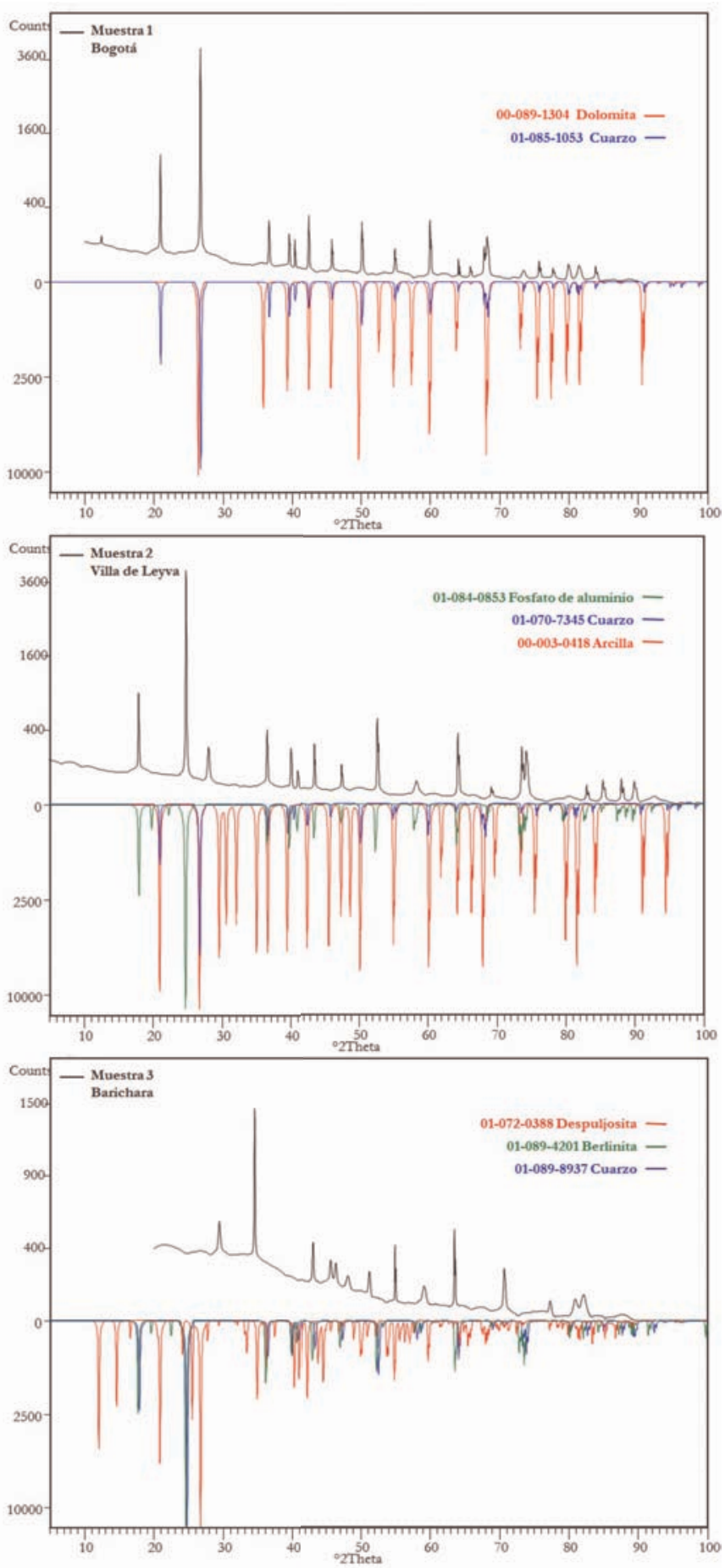

Fig 2. FTIR spectra and X-ray diffraction patterns of samples of mortars from the Casa Hacienda el Otoño in Bogotá (M1), Claustro de San Francisco in Villa de Leyva (M2) and House in Barichara (M3). 
de Leyva and at 873 and $469 \mathrm{~cm}^{-1}$ from Barichara, found by several authors (Böke et al. 2008, Gulotta et al. 2013).

Bands were identified for aluminosilicates $\left(\mathrm{Si}_{\mathrm{x}} \mathrm{Al}_{\mathrm{y}} \mathrm{O}_{\mathrm{z}}\right)$ at 1087 and $1033 \mathrm{~cm}^{-1}$ from Bogotá at 1077,1035 and $532 \mathrm{~cm}^{-1}$ from Villa de Leyva and at 1099,1033 and $538 \mathrm{~cm}^{-1}$ from Barichara. Vibrations at 1009, 1005, 1008 and $1007 \mathrm{~cm}^{-1}$ for samples from Bogotá, Villa de Leyva and Barichara correspond to the Al-O bond in hydrated aluminosilicates type compounds reported by several authors (Silva et al. 2005 and Gulotta et al. 2013). Si-O-Si and Si-O$\mathrm{Al}$ bonds, present in hydraulic compounds vibrated at 1008 and $914 \mathrm{~cm}^{-1}$ from Bogotá, at $914 \mathrm{~cm}^{-1}$ from Villa de Leyva and at 1008 and $913 \mathrm{~cm}^{-1}$ from Barichara.

Vibrations corresponding to $\mathrm{C}-\mathrm{H}$ bond stretching were seen in all samples at 2924 and $2853 \mathrm{~cm}^{-1}$ from Bogotá, at 2924 and $2855 \mathrm{~cm}^{-1}$ from Villa of Leyva and at 2923 and $2855 \mathrm{~cm}^{-1}$ from Barichara related to some kind of organic compound (Silva et al. 2005).

Gypsum $\mathrm{CaSO}_{4} \cdot 2 \mathrm{H}_{2} \mathrm{O}$ presented vibrations at 3693, 1618 and $1089 \mathrm{~cm}^{-1}$ from Bogotá; at 3647, 1628, 1076 and $714 \mathrm{~cm}^{-1}$ from Villa de Leyva, at $3651 \mathrm{~cm}^{-1}$ from Barichara; weddellite $\mathrm{CaC}_{2} \mathrm{O} \cdot \mathrm{H}_{2} \mathrm{O}$ at 1618 and $779 \mathrm{~cm}^{-1}$ from Bogotá; at 1628 and $779 \mathrm{~cm}^{-1}$ from Villa de Leyva and Barichara; calcite/ aragonite $\left(\mathrm{CaCO}_{3}\right)$ at 1425 and $876 \mathrm{~cm}^{-1}$ for Bogotá; at 1796, 1429, 874 and $714 \mathrm{~cm}^{-1}$ from Villa de Leyva, at 1441 and $874 \mathrm{~cm}^{-1}$ from Barichara. This data was compared to data found by several authors (Rampazzi et al. 2004, Lanas et al. 2005 Böke et al. 2008, Mleza and Hajjaji 2012).

Apatite $\mathrm{A}\left(\mathrm{Ca}_{5}\left(\mathrm{PO}_{4}\right)\right)_{2} \mathrm{CO}_{3}$ vibrates at 1088,1034 y $471 \mathrm{~cm}^{-1}$ for Bogotá; at 1076, 1036 and $469 \mathrm{~cm}^{-1}$ for Villa de Leyva; at 1456, 1099 and $1034 \mathrm{~cm}^{-1}$ for Barichara; carbonates $\mathrm{CO}_{3}{ }^{2-}$ at 1425 and $876 \mathrm{~cm}^{-1}$ for Bogotá; at 2509, 1796, 1429, 874 and 714 $\mathrm{cm}^{-1}$ for Villa de Leyva; at $874 \mathrm{~cm}^{-1}$ for Barichara. Vibrations for limestone $\left(\mathrm{CaCO}_{3} / \mathrm{SiO}_{2}\right)$ were found at 1425,876 and $471 \mathrm{~cm}^{-1}$ for Bogotá; at 1429, 874,714 and $469 \mathrm{~cm}^{-1}$ for Villa de Leyva and at 874 and $469 \mathrm{~cm}^{-1}$ for Barichara. Silicate bending and stretching bands $\mathrm{SiO}_{\mathrm{x}}$ were observed at 1034 and $797 \mathrm{~cm}^{-1}$ for Bogotá; at 1036, 797 and $532 \mathrm{~cm}^{-1}$ for Villa de Leyva and at 1034, 797 and $538 \mathrm{~cm}^{-1}$ for Barichara; the same for silica $\mathrm{SiO}_{2}$ at 797, 779, 694 and $471 \mathrm{~cm}^{-1}$ for Bogotá; at 1076, 797, 779, 694 and $469 \mathrm{~cm}^{-1}$ for Villa de Leyva and at 1099, 797, 779, $694 \mathrm{y} 469 \mathrm{~cm}^{-1}$ for Barichara, of accordance with several authors (Rampazzi et al. 2004, Lanas et al. 2005, Böke et al. 2008, Mleza and Hajjaji 2012).

The vibrations corresponding to the stretching of the O-H bond and $\mathrm{H}-\mathrm{O}-\mathrm{H}$ bending mode of hydration waters $\mathrm{H}_{2} \mathrm{O}$ were found at 3427 and $1625 \mathrm{~cm}^{-1}$ from Bogotá; at 3441 and $1628 \mathrm{~cm}^{-1}$ from Villa de Leyva, at 3427 and $1640 \mathrm{~cm}^{-1}$ from Barichara. The doublet in vibrations from 2360 and $2335 \mathrm{~cm}^{-1}$ corresponds to the compound, carbon dioxide, present in the atmosphere, dissolved in the samples from Bogotá, Villa de Leyva and Barichara. Stretching for bond $\mathrm{Al}-\mathrm{Al}-\mathrm{OH}$ in mica/illite was observed at $3620 \mathrm{~cm}^{-1}$ for Bogotá and Barichara. In portlandite $\mathrm{Ca}(\mathrm{OH})_{2} \mathrm{OH}$ stretching is evidenced on the band at $3693 \mathrm{~cm}^{-1}$ for Bogotá, $3699 \mathrm{~cm}^{-1}$ for Villa de Leyva and at 3695 and $1441 \mathrm{~cm}^{-1}$ for Barichara. Nitrates $\mathrm{NO}_{3}^{-1}$ and sulfites $\mathrm{SO}_{3}^{-2}$ present vibrations at 1385 and $934 \mathrm{~cm}^{-1}$ from Villa de Leyva and Barichara, respectively, described by several authors (Garg et al. 1995, Callebaut et al. 2001, Lanas et al. 2005, Mleza and Hajjaji 2012).

$\mathrm{X}$-raydiffraction (XRD): In the X-ray diffractograms of the samples (Figure 2) we found narrow peaks and of greater intensity with the increase of retention time, indicating good crystallinity (Table 3). The qualitative analysis of each one of the diffractograms presented the corresponding reflections for the identified compounds based on the diffraction profile found in the PDF-2 database of the International Center for Diffraction Data (ICDD). In the sample from Bogotá, compounds such as syn quartz $\left(\mathrm{SiO}_{2}\right.$, ICDD 01-085-1053) and dolomite $\left(\mathrm{CaMg}\left(\mathrm{CO}_{3}\right)_{2}\right.$,

Table 3. Comparison: presence $(\mathrm{P})$ and absence $(\mathrm{A})$ in compound samples found by XRD.

\begin{tabular}{lccc}
\hline Parameter & Bogotá & $\begin{array}{l}\text { Villa de } \\
\text { Leyva }\end{array}$ & Barichara \\
\hline Quartz $\mathrm{SiO}_{2}$ & $\mathrm{P}$ & $\mathrm{P}$ & $\mathrm{P}$ \\
Dolomite $\mathrm{CaMg}\left(\mathrm{CO}_{3}\right)_{2}$ & $\mathrm{P}$ & $\mathrm{A}$ & $\mathrm{A}$ \\
Aluminum $(\mathrm{III}) \mathrm{AlPO}_{4}$ & $\mathrm{~A}$ & $\mathrm{P}$ & $\mathrm{A}$ \\
phosphate $(\mathrm{V})$ & & & \\
Berlinite $\mathrm{Al}\left(\mathrm{PO}_{4}\right)$ & $\mathrm{A}$ & $\mathrm{A}$ & $\mathrm{P}$ \\
Despujolsite $\mathrm{Ca}_{3} \mathrm{Mn}$ & $\mathrm{A}$ & $\mathrm{A}$ & $\mathrm{P}$ \\
$\left(\mathrm{SO}_{4}\right)_{2}(\mathrm{OH})_{6}\left(\mathrm{H}_{2} \mathrm{O}\right)_{3}$ & & & \\
\hline
\end{tabular}


ICDD 00-089-1304) were identified. Villa de Leyva presented phases corresponding to syn quartz $\left(\alpha-\mathrm{SiO}_{2}, \quad\right.$ ICDD01-070-7345), aluminum (III) $\left(\mathrm{AlPO}_{4}, \mathrm{ICDD}_{01-084-0853)}\right.$ phosphate (V) and clayey aggregate (CaMgAlSiO, ICDD 00-003 to 0418). Compounds such as despujolsite $\left(\mathrm{Ca}_{3} \mathrm{Mn}\right.$ $\left(\mathrm{SO}_{4}\right)_{2}(\mathrm{OH})_{6}\left(\mathrm{H}_{2} \mathrm{O}\right)_{3}$, ICDD 01-072-0388); syn berlinite $\left(\mathrm{Al}\left(\mathrm{PO}_{4}\right)\right.$, ICDD 01-089-4201) and quartz $\left(\mathrm{SiO}_{2}, \mathrm{ICDD}\right.$ 01-089-8937), were identified in sample 3.

\section{Scanning electron microscopy (SEM-EDX):} On the images obtained by SEM, for all samples, there were aggregates of irregular crystal-type morphology of diameters between 50 and $100 \mu \mathrm{m}$ and agglomerated particles of approximately $10 \mu \mathrm{m}$. Organic fibers of a thicknesses exceeding $20 \mu \mathrm{m}$ were found in all samples (Figure 3).

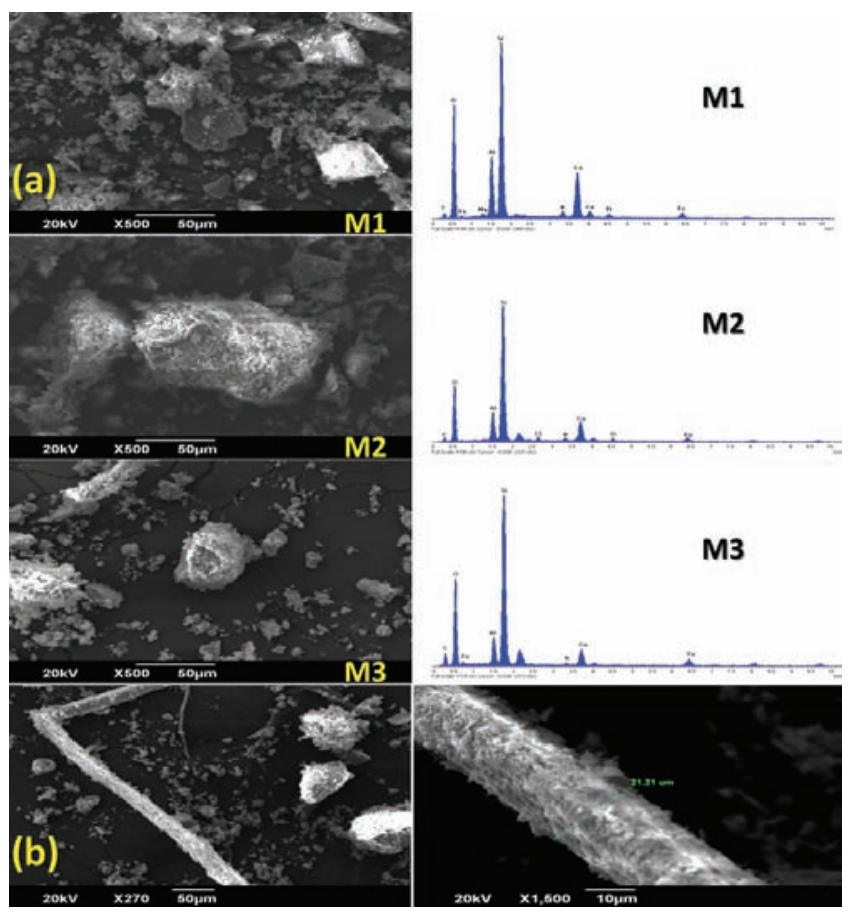

Fig 3. (a) SEM images and EDX spectra of mortar samples from the Casa Hacienda el Otońo in Bogotá (M1), Claustro de San Francisco in Villa de Leyva (M2) and House Barichara (M3). (b) SEM images of fibers found in mortars.

Microbiological analysis: The $\mathrm{CFU} / \mathrm{mL}$ count, showed that in the sample from Bogotá $108 \pm 2.4$ $\mathrm{CFU} / \mathrm{mL}$ and $198 \pm 0.8 \mathrm{CFU} / \mathrm{mL}$ were found in dilutions of $10^{-4}$ and $10^{-5}$, respectively. Unlike
Barichara with $10 \pm 0.8 \mathrm{CFU} / \mathrm{mL}$ and $14 \pm 0.8$ $\mathrm{CFU} / \mathrm{mL}$ and Villa de Leyva with $8 \pm 0.8 \mathrm{CFU} / \mathrm{mL}$ and $10 \pm 1.6 \mathrm{CFU} / \mathrm{mL}$. Six fungal individuals were identified, 4 of them of the Phylum Ascomycota, and 2 of the Phylum Zigomycota according to taxonomic keys. The genera identified were: Aspergillus, Penicillium, Alternaria, Fusarium, Mucor and Syncephalastrum (Figure 4).

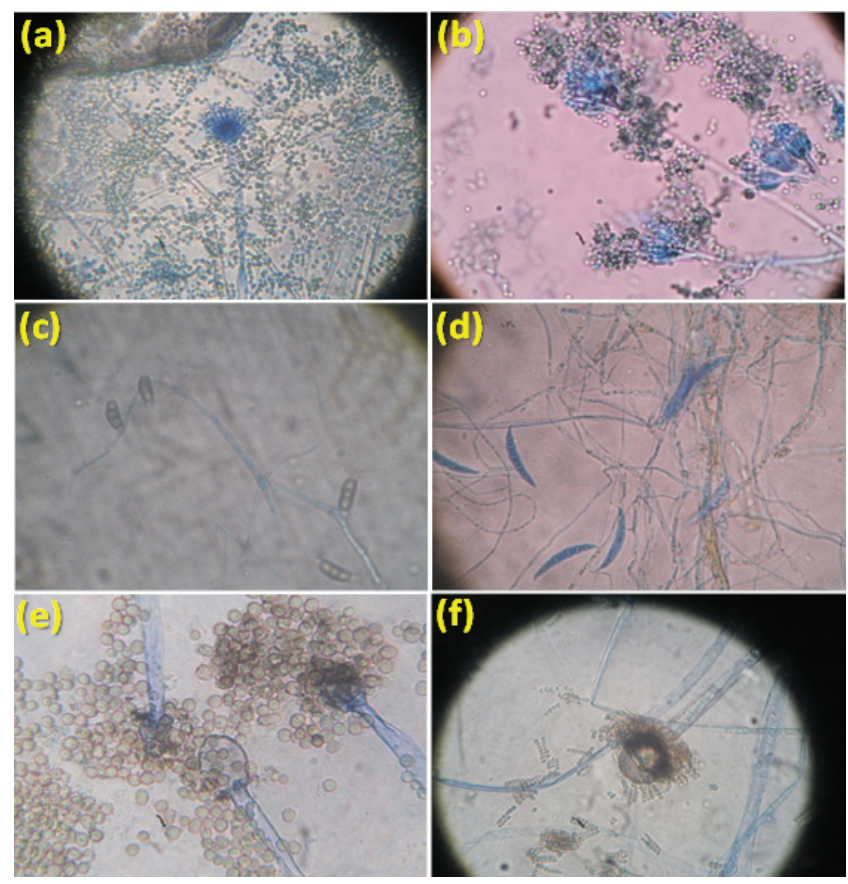

Fig. 4. Microscopy 40X de (a) Aspergillus. (b) Penicillum. (c) Alternaria. (d) Fusarium. (e) Mucor. (f) Syncephalastrum.

\section{Discussion}

Biodeterioration is a result of a combination of several factors such as microorganisms, the characteristics of the substrate and environmental conditions (Caneva et al. 2000). Microorganisms are largely responsible for the biodeterioration of mortars, as they are able to colonize an assimilable substrate and convert other compounds that are not assimilable into simpler forms (Sterflinger et al. 1999, Herrera et al. 2004). Garg et al. (1995), Sand (1997), Herrera et al. (2004) and Herrera and Videla (2004) found that Aspergillus, Penicillium, Alternaria, Fusarium, Mucor and Syncephalastrum generate biodeterioration of 
the mortar at a macro and microscopic level and affect their chemical characteristics, these results are similar to those obtained by this study, which reports the same fungal genera.

In turn, environmental conditions are determining factors for microorganism colonization and growth, in this case fungi. Relative humidity, temperature and rainfall vary by geographic area (Agrawal et al. 1988, Gaylarde et al. 2006, Sterflinger 2010, Mleza and Hajjaji 2012) and alters the composition of microbiota in the mortar (Garg et al. 1995 and Sterflinger 2010). Consistent with the results, colony-forming units were higher in Bogotá than they were in Villa de Leyva and Barichara. Relative humidity and precipitation are limiting factors, when their values are close to the limits of tolerance of a fungal genus (Caneva et al. 2000). Furthermore, temperature influences relative humidity as well as the water content in the substrate, since a constant value of water content and a high temperature equals lower relative humidity, that limits the number of fungal microorganisms, this is the case of Villa de Leyva and Barichara. Lastly, lower temperatures produce higher relative humidity (Bogotá) creating a favorable biotype for the development of fungi, which could explain the differences in colony forming units in the three samples.

The samples presenting the least fungal biodeterioration, reflected by the oxidized metals measured using atomic absorption, were Villa de Leyva and Barichara. Villa de Leyva presented high levels of tropical humidity and pollution, followed by Barichara. However, Bogotá presented the highest overall. These two elements facilitate biodeterioration; moisture makes the mortar porous, then rains wash away the soluble calcium carbonate and subsequently causes leaching (De la Torre 1993). Similarly, sulfur dioxide derived from human activities and the presence of sulfates in the environment and other types of contaminants, when combined with water ions produce sulfuric acid, which degrades the calcium in the mortar into calcium sulfite and minerals such as gypsum that diminish the amount of aluminum and iron in the walls (Corvo et al. 2010). Other contaminants like carbon monoxide and carbon dioxide may become carbonic acid in the presence of moisture and can reach dissolve the carbonates and degenerate the silicates in the walls. This is evidenced by the presence of soluble and insoluble compounds such as quartz, calcite and aragonite in samples from Villa de Leyva and Barichara (Barbera 2006, Gadd 2007, Corvo et al. 2010). Nitric oxide can also corrode metals in the walls and is an important contaminant to consider.

However, environmental factors, both biological and chemical, must be considered as a whole, the interaction between them may result in different effects of biodeterioration, as in the present case, where mortar composition is critical for optimal colonization and fungal growth. The results described found metal oxides ( $\mathrm{Ca}, \mathrm{Fe}, \mathrm{Si}, \mathrm{Al}$ and $\mathrm{Mg}$ ), traces of organic compounds and insoluble minerals from secondary metabolite reactions with the components of the wall, these are all considered nutrients, separated into macronutrients $(\mathrm{K}, \mathrm{Ca}, \mathrm{S}$, $\mathrm{Mg}, \mathrm{P}$ and $\mathrm{N}$ salts) if needed in large quantities, or micronutrients ( $\mathrm{Mn}, \mathrm{Fe}, \mathrm{Zn}$ and $\mathrm{Si}$ ) if necessary in low quantities (Gadd 2007, Gutarowska 2010).

Lime $(\mathrm{CaO})$ is the main compound degraded by fungal microorganisms, as evidenced by the analysis of the sample from Bogotá that had the highest amount of fungi and relative humidity, in comparison to the samples from Villa de Leyva and Barichara. The sample from Barichara had the least fungi and least humidity, followed by the sample from Villa de Leyva, which had a higher amount of fungi and relative humidity. The statistical analysis demonstrated that the sample from Bogotá presented the least amount of lime, this due to the high presence of fungal microorganisms and a clear difference in the relative humidity. The second compound with the most fungal biodegradation rate was silica $\left(\mathrm{SiO}_{2}\right)$. Silica is highly impacted by moisture generated mostly by rain, which in turn promotes the presence of microorganisms that deplete the silica content. Although statistical analysis did not establish significant differences, according to averages, the samples with higher silica content is Barichara, followed by Villa de Leyva and Bogotá (Gadd 2007, Corvo et al. 2010).

Metals such as aluminum (alumina), iron metal species (hematite) and magnesium, have higher values in the sample from Villa de Leyva than the sample from Bogotá, explained by the high concentration of fungi, in turn, the values of these metals are lower in the sample Barichara because of 
the type of materials (lime, soil and sand) used at the time of construction of the building (López 2009).

Microorganisms may attack the minerals in the cement paste; materials such as portlandite, silicates and calcium aluminates, as well as aggregates like quartz, feldspar and mica, all identified using the FTIR method. Warscheid-Braams (2000) and Gadd (2007) mention that the fungi attack the cement paste from bad interventions on the soil, solubilizing calcium products, by removing the silicium and by the oxidation of iron species, magnesium and other metals. Similarly, these fungi solubilize minerals and metal compounds by acidolysis mechanisms (chemolithotrophic processes with inorganic acids such as nitric and sulfuric acid) and complexolysis (chemolithotrophic processes with organic acids), as evidenced in the results obtained in this study (lime, hematite, alumina and magnesium). On the other hand, anion and cation reactions that lead to the oxidation of a metal known as redoxolysis were evidenced in the oxidation of the metals present in mortars (Warscheid-Braams 2000, Pinheiro and Silva 2003).

The presence of atmospheric and anthropogenic air pollution favor the generation of hydrocarbons and volatile compounds (Garg et al. 1995) and aid in the colonization and growth of fungi (Herrera et al. 2004, Rampazzi et al. 2004, Suhiko et al. 2007), this was corroborated by the results of loss on ignition, indicating a greater presence of volatile compounds and organic material in the sample taken from Bogotá than in those taken from the other two cities. This is because Bogotá is the capital and a large city; therefore, the levels of air pollution are higher (Gaitan et al. 2007) than in Villa de Leyva and Barichara. Also, the presence of fungioriginated organic matter in the sample from Bogotá is considerably higher than in the other two samples.

Genres such as Aspergillus and Alternaria have been reported by Garg et al. (1995) and Gadd (2007) as able to hydrolyze and solubilize metals for their assimilation as a nutritional source. Secondary fungi metabolites have the ability to react with iron ions and magnesium, oxidizing them, contributing to the deterioration of the construction. Mycogenic compounds such as calcium nitrate, ettringite and gypsum are produced from this type of biodegradation; this is evident in the decline of aluminum and iron in the mortar (Gadd 1999, Pinheiro and Silva 2003, Suhiko et al. 2007). The previous was exposed by the atomic absorption measurements and the decrease in alumina and hematite.

Some fungi produce polyols as osmoprotectants in response to water stress, these polyols and other polysaccharides bind to silicated compounds via hydrogen bridges such as mica and feldspar, found in this study, causing expansion in the crystalline layers of the plaster, as a result weakening the material (Gadd 2007) one of the features required of the samples taken during our sample collection.

Some of the secondary fungi metabolites existing in the outer coatings of the walls secrete organic acids such as glucuronic acid, citric acid, malic acid and oxalic acid. The production of such acids creates a proton source, which is made available to carry out oxidation reactions that help solubilize certain metals (Sorlini et al. 1982). In turn, organic acids degrade the components in the mortar, generating compounds of fungal origin, that cause different chemical-physical effects. Calcium oxalate, which is the product of the reaction of calcium ions in the mortar and the oxalic acid secreted by the fungus, produces minerals such as weddelite and whewellite by hydration (Garg et al. 1995, Rampazzi et al. 2004). These were all found in this study and in all of the samples, but mostly in Bogotá, contrastingly with the insoluble residue values found in the three samples. Although the statistical analysis showed no significant differences, trends in the variables corroborate the previous. This organic acid secreted by the fungus also reacts with metal ions in the mortar such as iron, magnesium and aluminum, when oxidized and degraded by the general mechanism of the reaction: $\mathrm{M}^{3+}+3 \mathrm{C}_{2} \mathrm{O}_{4}{ }^{2-} \rightarrow \mathrm{M}\left(\mathrm{C}_{2} \mathrm{O}_{4}\right)_{3}{ }^{3-}$, causing visible and significant damage to the aesthetics and integrity of the architectural covering making it difficult to restore the mortar (De la Torre 1993, Goméz-Alarcon and De la Torre 1994, GomézAlarcon et al. 1995, Sand 1997, Gutarowska 2010).

The simplest salts are those from the reaction of oxalic acid with a metal (oxalates). They are not very soluble and precipitate as amorphous crystalline solids. The secretion of organic acids results in calcium oxalate, which generates a variety of crystal structures and has a direct association with fungi. 
Its main forms are the monohydrate (whewellite) and the dihydrate (whedellite) (Gadd 1999, Gorny 2004), unlike those encountered in scanning electron microscopy, where the crystals observed have an irregular morphology with diameters ranging between 50 and $100 \mu \mathrm{m}$ and are insoluble, which affect the nutritional heterogeneity of elements $\mathrm{Ca}$, $\mathrm{P}, \mathrm{K}$ and $\mathrm{Al}$ in the three mortar samples.

As evidenced in this study, a chemical and microbiological analysis may be useful to create an effective plan of action to eliminate and prevent biodeterioration. Giving restorers and curators the tools to understand the biological and chemical aspects of biodeterioration, so they can apply this knowledge of microbiology and chemistry to the conservation of heritage works.

\section{Conclusion}

The comparison of the samples taken from different heritage constructions and the statistical analysis of their components proved that the chemical composition of each one of the mortars is different. The analysis also evidenced the presence of metal degrading fungi in the mortars taken from Bogotá, which affect materials such as calcium, silicium, aluminum, iron and magnesium, unlike the samples taken from Villa de Leyva and Barichara that do not present these fungi. The evidence of these metal oxides and other compounds such as gypsum, weddellite, despujolsite, quartz, berlinite, carbonate, mica, feldspar and silicate is mainly due to the biological interaction of the fungi Aspergillus, Penicillium, Alternaria, Fusarium, Mucor and Syncephalastrum found in the mortars from Bogotá, Villa de Leyva and Barichara. However, the sample from Bogotá had the highest number of colony forming units $(\mathrm{CFU} / \mathrm{mL})$ and a higher relative humidity than the samples from Villa de Leyva and Barichara, this is a decisive factor for fungal colonization.

\section{Acknowledgements}

The authors acknowledge the collaboration, time and support to Dr. Miguel Angel Ramos Garcia, Coordinator of the X-Ray Diffraction Laboratory and X-Ray Fluorescence, Unit Materials Characterization and Structure of Instituto Zuliano de Investigaciones Tecnológicas de Venezuela. To Andrea Garcia Caycedo M.Sc. Coordinator of the Microbial Chemistry Laboratory, Department of Chemistry at the Pontificia Universidad Javeriana and our collaborator, Carlos Enrique Parada Parra, member of the Atomic Absorption and Emission Laboratory and the Microbial Chemistry Laboratory of the Department of Chemistry at the Pontificia Universidad Javeriana. This work was funded by the Academic Vice-Rector's office at the Javeriana University, Project 3173. The authors are in agreement with the results published in this article and state no conflicts of interest exist.

\section{References}

Agilent Technologies (2012) Flame Atomic Absorption Spectrometry - Analytical Methods Part Number 85100009-00. Tenth Edition, Santa Clara, USA

Agrawal OP, Dhawan KL, Garg F, Shaheen N, Pathak N, Misra A (1988) Study of Biodeterioration of the Ajanta wall paintings. International Biodeterioration and Biodegration 24(2): $121-129$ doi 10.1016/02653036(88)90054-1

Barichara (2011) http://www.barichara-santander.gov. co. Consulted on July 14th of 2011

BarberáXM. (2006) Estudio y caracterización de morteros compuestos, para su aplicación en intervenciones de sellados, reposiciones y réplicas, de elementos pétreos escultórico-ornamentales. Tesis de Doctorado. Facultat de Belles arts de Sant Carles. Universitat Politecnica de Valencia

Böke H, Cizer Ö, Ipekoglu B, Ugurlu E, Serifaki K, Toprak G (2008) Characteristics of lime produced from limestone containing diatoms. Construction and Building Material 22(5): 866-874 doi 10.1016/j. conbuildmat.2006.12.010

Callebaut K, Elsen J, Van Balen K, Viaene W (2001) Nineteenth century hydraulic restoration mortars in the Saint Michael's Church (Leuven, Belgium) Natural hydraulic lime or cement?. Cement and Concrete Research 31(3): 397-403 doi 10.1016/S00088846(00)00499-3

Caneva G, Nugari MP, Salvadori O (2000) La biología en la restauración: arte y restauración. Editorial Nerea, Madrid/Sevilla, España

Corradine A (1989) Historia de la arquitectura colombiana. Editorial Escala, Bogotá DC, Colombia

Corvo F, Reyes J, Valdes C, Villaseñor F, Cuesta O, Aguilar D, Quintana P (2010) Influence of Air Pollution and Humidity on Limestone Materials Degradation in Historical Buildings Located in Cities Under Tropical Coastal Climates. Water Air and Soil Pollut 205: 359375 doi 10.1007/s11270-009-0081-1

De la Torre MA, Gomez-Alarcon G, Vizcaino C, 
Garcia MT (1993) Biochemical mechanisms of stone alteration carried out by filamentous fungi living in monuments. Biogeochemestry 19(3): 129-147 doi 10.1007/BF00000875

Gadd GM (1999) Fungal production of Citric and Oxalic Acid: Importance in metal speciation, physiology and biogeochemical processes. Advances in microbial physiology 41: 47-92 doi 10.1016/S00652911(08)60165-4

Gadd G (2007) Geomycology: biogeochemical transformations of rocks, minerals, metals and radionuclides by fungi, bioweathering and bioremediation. Mycological Research 111(1): 3-49 doi 10.1016/j.mycres.2006.12.001

Gaitán M, Cancino J, Behrentz E (2007) Análisis del estado de la calidad del aire en Bogotá. Revista de Ingeniería Universidad de los Andes. 26(1): 82-91

Garg KL, Kamal KJ, Mishra AK (1995) Role of fungi in the deterioration of wall paintings. Science of the Total Environment 167: 255-271 doi 10.1016/00489697(95)04587-Q

Gaylarde P, Englert G, Ortega-Morales O, Gaylarde C (2006) Lichen-like colonies of pure Trentepohlia on limestone momuments. International Biodeterioration and Biodegradation 58(3-4): 119-123 doi 10.1016/j. ibiod.2006.05.005

Gleize P, Silva DA, Nappi S (2000) Ancient rendering mortars from a Brazilian palace Its characteristics and microstructure. Cement and Concrete Research 30(10): 1609-1614 doi 10.1016/S0008-8846(00)00408-7

Gleize PJP, Motta EV, Silva DA, Roma HR (2009) Characterization of historical mortars from Santa Catalina (Brazil). Cementand Concrete Composites31(5): 342-346 doi 10.1016/j.cemconcomp.2009.02.013

Goméz-Alarcon G, Cilleros B, Flores M, Lorenzo J (1995) Microbial communities and alteration processes in momuments at Alcala de Henares, Spain. The science of total environment 167(1-3): 231-239 doi 10.1016/0048-9697(95)04584-N

Goméz-Alarcon G, De la Torre MA (1994) The effect of filamentous fungi on stone momuments: the Spanish Experience. In: Building mycology. Management of decay and health in building. Chapman and Hall, UK, pp 295-309

Górny RL (2004) Filamentous microorganisms and their fragments in indoor air - A review. Annals of Agricultural and Environmental Medicine 11(2): 185197

Gulotta D, Goidanich S, Tedeschi C, Nijland TG, Toniolo L (2013) Commercial NHL-containing mortars for the preservation of historical architecture. Part 1: Compositional and mechanical characterization. Construction and Building Materials 38: 31-42 doi 10.1016/j.conbuildmat.2012.08.029

Gutarowska B (2010) Metabolic activity of moulds as a factor of building materials biodegradation. Polish
Journal of Microbiology 59(2): 119-124

Heitz E, Mercer AD, Sand W, Tiller AK (1990) Microbiological degradation of materials and methods of protection. European Federation of Corrosion Publications 2: 1-88

Herrera L, Videla H (2004) The importance of atmospheric effects on biodeterioration of cultural heritage constructional materials. International Biodeterioration and Biodegradation 54(2-3): 125-134 doi 10.1016/j.ibiod.2004.06.002

Herrera LK, Arroyavea C, Guiametb P, Gomez de Saravia S, Videla H (2004) Biodeterioration of peridotite and other constructional materials in a building of the Colombian cultural heritage. International Biodeterioration and Biodegradation 54(2-3): 135 141 doi 10.1016/j.ibiod.2004.06.001

Hirsh P, Eckhardt FEW, Palmer RJ (1995) Methods for the study of rock-inhabiting microorganisms. Journal of Microbiological Methods 23(2): 143-167 doi 10.1016/0167-7012(95)00017-F

Ideam (2012) http://institucional.ideam.gov.co/jsp/ index.jsf. Consulted on November 19th of 2012

Lanas J, Sirera R, Alvarez JI (2005) Compositional changes in lime-based mortars exposed to different environments. Thermochimica Acta 429(2): 219-226 doi 10.1016/j.tca.2005.03.015

López PC (2009) Plan Especial de Manejo y Protección, Casa de hacienda el Otoño. Inédito. Bogotá, Colombia

Mleza Y, Hajjaji M (2012) Microstructural characterisation and physical properties of cured thermally activated clay-lime blends. Construction and Building Materials 26(1): 226-232 doi 10.1016/j. conbuildmat.2011.06.014

Pinheiro SMM, Ribas Silva M (2003) Alteration of the concrete microstructure promoted by biodeterioration mechanisms. In: RILEM International Conference on Microbial Impact on Building Materials. RILEM Publications SARL, Bagneux, France, pp 48-57

Nuhoglu Y, Oguz E, Uslu H, Ozbek A, Ipekoglu B, Ocak I, Hasenekoglu I (2006) The accelerating effects of the microorganisms on biodeterioration of stone monuments under air pollution and continental-cold climatic conditions in Erzurum, Turkey. Science of Total Environment 364(1-3): 272-283 doi 10.1016/j. scitotenv.2005.06.034

Quarcioni VA, Cincotto MA (2006) Optimization of calculation method for determination of composition of hardened mortars or Portland cement and hydrated lime made in laboratory. Construction and Building Material 20(10): 1069-1078 doi 10.1016/j. conbuildmat.2005.02.028

Rampazzi L, Andreotti A, Bonaduce I, Colombini MP, Colombo C, Toniolo L (2004) Analytical investigation of calcium oxalate films on marble monuments. Talanta 63(4): 967-977 doi 10.1016/j.talanta.2004.01.005

Samson RA, Hoekstra ES, Frisvad JC (2004) Introduction 
to food and airborne fungi. American Society for Microbiology Press, New York, USA

Sand W (1997) Microbial mechanisms of deterioration of inorganic substrates - A general mechanistic overview. International Biodeterioration and Biodegradation 40(24): 183-190 doi 10.1016/S0964-8305(97)00048-6

Sanjurjo-Sánchez J, Trindade MJ, Blanco-Rotea R, Benavides García R, Fernández Mosquera D, Burbidge C, Prudencio MI, Dias MI (2010) Chemical and mineralogical characterization of historic mortars from the Santa Eulalia de Bóveda temple, NW Spain. Journal of Archaeological Science 37(9): 2346-2351 doi 10.1016/j.jas.2010.04.008

Silva DA, Wenk HR, Monteiro PJM (2005) Comparative investigation of mortars from Roman Colosseum and cistern. Thermochimica Acta 438(1-2): 35-40 doi 10.1016/j.tca.2005.03.003

Sorlini C, Allievi M, Sacchi, Ferrari A (1982) Microorganisms present in deteriorated material of de Palazzo della Ragione in Milan. International Biodeterioration and Biodegradation 18: 105-110

Sterflinger A (2010) Fungi: their role in deterioration of culture heritage. Fungal biology reviews 24(1-2): 47-55 doi 10.1016/j.fbr.2010.03.003

Sterflinger K, Krumbein WE, Rullkötter J (1999) Patination of marble sandstone and granite by microbial communities. Zietschrift der deutschen geologischen gesellschaft 150(2): 299-311

Suhiko ML, Alakomi HL, Gorbushima A, Fortune I, Marquardt J, Saarela M (2007) Characterization of aerobic bacterial and fungal microbiota on surfaces of historic Scottish monuments. Systematic and applied microbiology 30(6): 494-508 doi 10.1016/j. syapm.2007.05.001

Ventola L, Vendrell M, Giraldez P, Merino L (2011) Traditional organic additives improve lime mortars: New old materials for restoration and building natural Stonefabrics. Construction and Building Materials25(8): 3313-3318 doi 10.1016/j.conbuildmat.2011.03.020

Warscheid Th, Braams J (2000) Biodeterioration of stone: a review. International Biodeterioration and Biodegradation 46(4): 343-368 doi 10.1016/S09648305(00)00109-8 